\title{
PENERAPAN STRATEGI PEMBELAJARAN A REACTION TO VIDEO UNTUK MENINGKATKAN MOTIVASI DAN HASIL BELAJAR IPA FISIKA MATERI POKOK SISTEM TATA SURYA KELAS VIII-A SMP NEGERI 1 SITUBONDO TAHUN PELAJARAN 2016/2017
}

\author{
Parwihastuti ${ }^{1}$ \\ ${ }^{1}$ SMP Negeri 1 Situbondo \\ Email : par.hastuti@gail.com
}

Received: July 25, $2021 \quad$ Revised: July 30, $2021 \quad$ Accepted: Augst 5, 2021

\begin{abstract}
ABSTRAK
Berdasarkan hasil observasi yang menunjukkan bahwa pembelajaran di SMP Negeri 1 Situbondo Situbondo khususnya siswa kelas VIII masih di bawah rata-rata hasil belajarnya. Hal ini disebabkan karena (1) Guru jarang membentuk kelompok bahkan tidak pernah menggunakan model-model pembelajaran yang bervariasi sehingga membuat siswa terkesan bosan, (2) kurang adanya diskusi antara siswa dengan guru sehingga dalam kelas terasa pasif dalam pembelajaran, (3) materi yang diajarkan kurang mengacu pada pengalaman siswa, guru perlu menggunakan teks book dalam mengajar, (4) guru kurang memberikan kesempatan kepada siswa untuk melakukan penerapannya sendiri, (5) dalam membentuk kelompok kurang heterogen dalam memilih anggota kelompok, (6) umumnya motivasi siswa belajar IPA masih rendah. Desain penelitian dalam penelitian ini adalah PTK dengan berkolaborasi dengan guru yang dilakukan 2 siklus. Dalam PTK ada 4 tahapan yaitu perencanaan, tindakan, observasi dan refleksi. Data primer dengan menggunakan tes ulangan dan observasi dengan di checklist, dan data sekunder dengan wawancara. Peneliti menggunakan keharusan nilai sasaran atau KKM (Kriteria Ketuntasan Minimal) menentukan kriteria sukses untuk menganalisis data. Berdasarkan hasil pembahasan dapat disimpulkan penerapan strategi pembelajaran a reaction to video dapat meningkatkan motivasi belajar siswa mencapai $24 \%$ dari $67 \%$ siklus I menjadi 91\% siklus II IPA Fisika materi pokok sistem tata surya kelas VIII-A SMP Negeri 1 Situbondo Tahun Pelajaran 2016/2017 dan penerapan strategi pembelajaran a reaction to video dapat meningkatkan hasil belajar siswa mencapai $19 \%$ dari $69 \%$ siklus I menjadi $91 \%$ siklus II IPA Fisika materi pokok sistem tata surya kelas VIII-A SMP Negeri 1 Situbondo Tahun Pelajaran 2016/2017.
\end{abstract}

Kata Kunci : Strategi Pembelajaran a Reaction to Video, Motivasi, Hasil Belajar

\section{PENDAHULUAN}

Ilmu Pengetahuan Alam (IPA) berkaitan dengan cara mencari tahu tentang alam semesta secara sistematis. IPA bukan hanya penguasaan kumpulan pengetahuan yang berupa fakta, konsep, dan prosedur tetapi juga merupakan suatu proses penemuan. Pendidikan IPA diharapkan dapat menjadi wahana bagi siswa untuk mempelajari diri 
sendiri dan alam sekitar, serta prospek pengembangan lebih lanjut untuk menerapkannya dalam kehidupan sehari-hari. Proses pembelajaran IPA menekankan pada pemberian pengalaman langsung untuk mengembangkan kompetensi dan memahami alam sekitar secara ilmiah (Kemdikbud, 2014). Selanjutnya, Taufik dkk. (2010) mengemukakan bahwa IPA adalah pembelajaran yang tidak mengabaikan proses sains. Hakikat sains yang dimaksud meliputi produk, proses, dan sikap ilmiah. Pembelajaran IPA seharusnya dapat memberikan pengalaman langsung pada siswa sehingga menambah kemampuan dalam mengkonstruksi, memahami, dan menerapkan konsep yang telah dipelajari. Dengan demikian, siswa akan terlatih menemukan sendiri berbagai konsep secara holistik, bermakna, autentik serta aplikatif untuk kepentingan pemecahan masalah.

Pembelajaran hendaknya memperhatikan perbedaan-perbedaan individual siswa tersebut, sehingga pembelajaran benar-benar dapat merobah kondisi siswa dari yang tidak tahu menjadi tahu, dari yang tidak paham menjadi paham serta dari yang berperilaku kurang baik menjadi baik. Kondisi riil siswa seperti ini, selama ini kurang mendapat perhatian di kalangan pendidik.

Hal ini terlihat dari perhatian sebagian guru/pendidik yang cenderung memperhatikan kelas secara keseluruhan, tidak perorangan atau kelompok anak, sehingga perbedaan individual kurang mendapat perhatian. Gejala yang lain terlihat pada kenyataan banyaknya guru yang menggunakan metode pengajaran yang cenderung sama setiap kali pertemuan di kelas berlangsung. Pembelajaran yang kurang memperhatikan perbedaan individual siswa dan didasarkan pada keinginan guru, akan sulit untuk dapat mengantarkan siswa ke arah pencapaian tujuan pembelajaran. Kondisi seperti inilah yang pada umumnya terjadi pada pembelajaran konvensional.

Konsekuensi dari pendekatan pembelajaran seperti ini adalah terjadinya kesenjangan yang nyata antara siswa yang cerdas dan siswa yang kurang cerdas dalam pencapaian tujuan pembelajaran. Kondisi seperti ini mengakibatkan tidak diperolehnya ketuntasan dalam belajar, sehingga sistem belajar tuntas terabaikan. Hal ini membuktikan terjadinya kegagalan dalam proses pembelajaran di sekolah.

Hal ini sesuai dengan hasil observasi yang menunjukkan bahwa pembelajaran di SMP Negeri 1 Situbondo Situbondo khususnya siswa kelas VIII masih di bawah ratarata hasil belajarnya. Hal ini disebabkan karena (1) Guru jarang membentuk kelompok bahkan tidak pernah menggunakan model-model pembelajaran yang bervariasi sehingga membuat siswa terkesan bosan, (2) kurang adanya diskusi antara siswa dengan guru sehingga dalam kelas terasa pasif dalam pembelajaran, (3) materi yang diajarkan kurang 
mengacu pada pengalaman siswa, guru perlu menggunakan teks book dalam mengajar, (4) guru kurang memberikan kesempatan kepada siswa untuk melakukan penerapannya sendiri, (5) dalam membentuk kelompok kurang heterogen dalam memilih anggota kelompok, (6) umumnya motivasi siswa belajar IPA masih rendah. Kondisi ini mengakibatkan hasil belajar siswa menjadi kurang optimal. Dari uraian penyebab tersebut yang utama adalah guru kurang menggunakan metode yang bervariasi. Berdasarkan uraian tersebut dapat mempengaruhi pada hasil belajar mencapai dibawah KKM yaitu 70 sedangkan persentase siswa yang tidak tuntas mencapai 50\% atau 16 siswa dan siswa yang tuntas mencapai 16 siswa atau 50\%.

Salah satu usaha yang bisa dilakukan untuk mengatasi masalah-masalah tersebut adalah dengan memperbaiki metode pembelajaran Muhibbin Syah (2010:201) menyatakan bahwa metode mengajar adalah cara yang berisi prosedur baku untuk melaksanakan kegiatan kependidikan, khususnya kegiatan Penyajian materi pelajaran kepada siswa oleh karena itu, metode mengajar yang digunakan harus melibatkan siswa untuk aktif dalam kegiatan belajar mengajar. Menyadari kenyataan seperti ini para ahli berupaya untuk mencari dan merumuskan strategi yang dapat merangkul semua perbedaan yang dimiliki oleh siswa didik. Strategi pembelajaran yang ditawarkan adalah strategi belajar aktif (active learning strategy). Diharapkan strategi belajar aktif (active learning strategy) dapat menjadi suatu strategi untuk mengatasi kesulitan belajar siswa.

Strategi belajar aktif dengan a reaction to video yaitu memberikan informasi tentang materi yang ditayangkan oleh guru melalui video kemudian siswa memberikan reaksi atas video yang ditayang oleh guru berupa kritikan yang membangun. Harapan pembelajaran aktif melalui Strategi Pembelajaran $A$ reaction to video, siswa mampu mengorganisasikan kelas dan dapat menjelaskan pint-point penting dalam materi.

Dari uraian tersebut peneliti memilih judul Penerapan Strategi Pembelajaran $a$ Reaction to Video Untuk Meningkatkan Motivasi dan Hasil Belajar IPA Fisika materi pokok sistem tata surya kelas VIII-A SMP Negeri 1 Situbondo Tahun Pelajaran 2016/2017.

Terdapat berbagai macam pengertian strategi pembelajaran sebagai mana dikemukakan oleh para ahli. Salah satunya yang dikemukakan oleh Dick dan Carey sebagaimana dikutip Etin Solihatin (2012:3) yang menyatakan bahwa strategi pembelajaran adalah komponen umum dari suatu rangkaian materi dan prosedur pembelajaran yang akan digunakan secara bersama-sama oleh guru dan siswa selama 
proses pembelajaran berlangsung (Etin Solihatin, 2012: 3). Terdapat 5 komponen strategi pembelajaran yang perlu diperhatikan yakni kegiatan pembelajaran pendahuluan, penyampaian informasi, partisipasi peserta didik, tes, dan kegiatan lanjutan. Sedangkan menurut Etin Solihatin (2012:4) Strategi Pembelajaran adalah pendekatan secara menyeluruh dalam suatu sistem pembelajaran, yang berupa pedoman umum dan kerangka kegiatan untuk mencapai tujuan umum pembelajaran, yang melukiskan prosedur yang sistematis dalam membantu usaha belajar siswa, mengorganisasikan pengalaman belajar, mengatur dan merencanakan bahan ajar untuk mencapai tujuan pembelajaran tertentu.

Selain itu, menurut Darmayah (2010:17) strategi pembelajaran merupakan pengorganisasian isi pelajaran, penyampaian pelajaran dan pengelolaan kegiatan pembelajaran dengan menggunakan berbagai sumber belajar yang digunakan oleh guru guna menunjang terciptanya proses pembelajaran yang efektif dan efisien. Hal itu berarti bahwa strategi pembelajaran menggunakan berbagai sumber belajar yang digunakan oleh guru seperti menggunakan alat peraga, buku teks, dan kartu indeks dalam melaksanakan proses belajar mengajar di kelas sehingga pembelajaran dapat berlangsung secara efektif dan efisien. Berdasarkan beberapa definisi di atas, maka dapat disimpulkan bahwa strategi pembelajaran merupakan suatu prosedur pembelajaran dalam membantu usaha belajar siswa, mengorganisasikan pengalaman belajar, mengatur dan merencanakan bahan ajar, agar tercipta proses pembelajaran yang lebih efektif dan efisien untuk mencapai tujuan pembelajaran.

Menurut Kusniasih (2015:15) video reaksi adalah video di mana orang bereaksi terhadap peristiwa. Secara khusus, video yang menunjukkan reaksi emosional dari orang yang melihat episode serial televisi atau trailer film yang banyak dan populer di layanan hosting video. Orang yang digambarkan mungkin atau mungkin tidak menyadari bahwa mereka sedang direkam, dan video yang sedang bereaksi mungkin atau mungkin tidak direproduksi dalam video reaksi, yang memungkinkan pemirsa video reaksi untuk melihat secara langsung apa yang sedang bereaksi. Orang yang digambarkan mungkin atau mungkin tidak menyadari bahwa mereka sedang direkam, dan video yang sedang bereaksi mungkin atau mungkin tidak direproduksi dalam video reaksi, yang memungkinkan pemirsa video reaksi untuk melihat secara langsung apa yang sedang bereaksi. Strategi pembelajaran a reaction to video akan membuat siswa untuk lebih kreatif untuk menjawab pertanyaan berdasarkan pengalaman yang ditemukan sehari-hari. Sering, siswa dalam melihat video pendidikan secara pasif dan 
kurang bergairah. Siswa duduk manis dan menunggu acara selesaikan dan video dimatikan. Dengan strategi ini, siswa akan sungguh-sungguh dan memperhatikan secara seksama.

Pada hakikatnya IPA dikembangkan atas dasar proses ilmiah, sikap ilmiah dan produk ilmiah. IPA dapat dilihat pula sebagai proses, sebagai prosedur dan sebagai produk seperti yang dinyatakan oleh Trianto (2010). Proses diartikan semua kegiatan ilmiah untuk menyempurnakan tentang pengetahuan alam maupun menemukan pengetahuan baru. Produk diartikan hasil proses, berupa pengetahuan yang diajarkan di sekolah maupun di luar sekolah ataupun dari bacaan untuk penyebaran atau deseminasi pengetahuan. Prosedur memiliki arti metodologi atau cara yang dipakai untuk mengetahui sesuatu (riset pada umumnya) yang lazim disebut dengan metode ilmiah (scientific method). Daud Joesoef (1990) menganjurkan agar IPA dijadikan sebagai suatu "kebudayaan" atau suatu kelompok atau intitusi sosial dengan tradisi nilai, aspirasi maupun inspirasi. Produk IPA merupakan sekumpulan pengetahuan dan sekumpulan konsep dan bagan konsep. Trianto (2010) menyatakan bahwa IPA hakikatnya merupakan suatu proses, produk dan aplikasi. Sehingga IPA merupakan proses yang dipergunakan untuk mempelajari obyek studi, menemukan dan mengambangkan produk-produk sains dan sebagai aplikasi teori-teori IPA akan melahirkan teknologi yan dapat memberikan kemudahan bagi kehidupan. Secara umum IPA meliputi 3 bidang ilmu dasar yaitu biologi, fisika dan kimia, yang muncul dan berkembang melalui langkah-langkah observasi, perumusan masalah, penyusunan hipotesis, pengujian hipotesis melalui eksperimen, penarikan kesimpulan serta penemuan teori dan konsep.

Secara khusus fungsi dan tujuan IPA berdasarkan kurikulum 2013 yang berdasar kompetensi adalah sebagai berikut: (1) menanamkan keyakinan terhadap Tuhan Yang Maha Esa; (2) mengembangkan ketrampilan, sikap dan nilai ilmiah; (3) mempersiapkan siswa menjadi warga Negara yang melek sains dan teknologi; dan (4) menguasai konsep sains untuk bekal hidup di masyarakat dan melanjutkan pendidikan ke jenjang lebih tinggi. Fungsi dan tujuan tersebut jelas bahwa hakikat IPA tidak hanya dari demensi pengetahuan (keilmuan), tetapi juga demensi keilahian, dimana alam semesta dalam keteraturan dan keimbangan inilah yang akan meningkatkan keyakinan akan kekuatan diluar manusia atau boleh dikatakan kekuatan Tuhan Yang Maha Kuasa. IPA pada hakikatnya mengaitkan antara aspek logika material dengan aspek jiwa spiritual, yang pada umumnya dianggap cakrawala kosong, dikarenakan anggapan bahwa antara IPA 
dan agama merupakan dua sisi yang berbeda dan tidak mungkin dipersatukan satu sama lain dan satu bidang kajian. Trefil\& Hazen (2000:2) mengemukakan: " As you can see, all of the earth's systems an interrelated. A change in another system, which may cause more systems to change and so on. All things depend on all other things".

Strategi Pembelajaran a Reaction to Video guru sering menawarkan untuk bertanya atau menjawab pertanyaan atau pula melakukan sesuatu kepada siswa pada saat siswa melakukan praktek membantu siswa merumuskan apa yang mereka inginkan dan mengarahkan apa yang harus dilakukan siswa agar kompetensi yang diharapkan tercapai dalam pelajaran tersebut. Sehngga siswa akan memberikan reaksi terhadap stimulus yang diberikan oleh guru.

Strategi Pembelajaran a Reaction to Video adalah salah satu pembelajaran kontektual. Metode inkuiri adalah cara guru mengerjakan materi dengan merancang pembelajaran yang menuntut siswa untuk menemukan sendiri pengalaman belajar secara nyata. Jadi siswa diharapkan dapat berfikir secara kritis, logis, sistematis dalam pembelajaran tersebut sehingga siswa mempunyai pengalaman secara nyata dan ilmiah siswa tidak hanya menjadi objek pelaksana akan siswa sebagai subjek pelaksana.

Dengan adanya Strategi Pembelajaran a Reaction to Video diharapkan dapat meningkatkan motivasi belajar siswa. Karena pengajaran inkuiri mempunyai banyak variasi yang bisa diterapkan dalam pembelajaran sehingga siswa tidak akan merasa bosan atau jenuh. Dengan inovasi-inovasi yang muncul dalam pembelajaran inkuiri diharapkan dapat meningkatkan motivasi siswa dalam belajar. Motivasi belajar dari siswa akan muncul bisa karena dorongan dari dalam dirinya atau dari orang lain. Dengan Strategi Pembelajaran a Reaction to Video yang melibatkan teman, lingkungan, alat peraga akan dapat enumbuhkan rasa senang siswa terhadap pelajaran yang dipelajarinya. Sehingga motivasi ini juga akan mempengaruhi keinginan seorang siswa untuk belajar lebih giat, agar dapat mencapai keingintahuan yang mereka hadapi dan dapat mencapai kompetensi dasar dalam pembelajaran tersebut.

Rancangan penelitian yang dipandang sesuai dengan tujuan penelitian adalah rancangan penelitian tindakan kelas (PTK) karena menurut Hobri (2006) penelitian tindakan kelas adalah penelitian atau Kajian secara sistematis dan terencana yang dilakukan oleh peneliti dan praktisi (dalam hal ini guru) untuk memperbaiki pembelajaran dengan jalan mengadakan perbaikan atau perubahan dan mempelajari akibat yang ditimbulkan. 
Desain penelitian yang dipakai dalam penelitian ini adalah model skema spiral dari Hopkins (dalam Arikunto, 2006:94) dengan menggunakan empat fase yaitu: perencanaan, tindakan, observasi dan refleksi. Keempat fase tersebut merupakan suatu siklus untuk melaksanakan penelitian tindakan kelas ditunjukkan dengan bagan berikut:

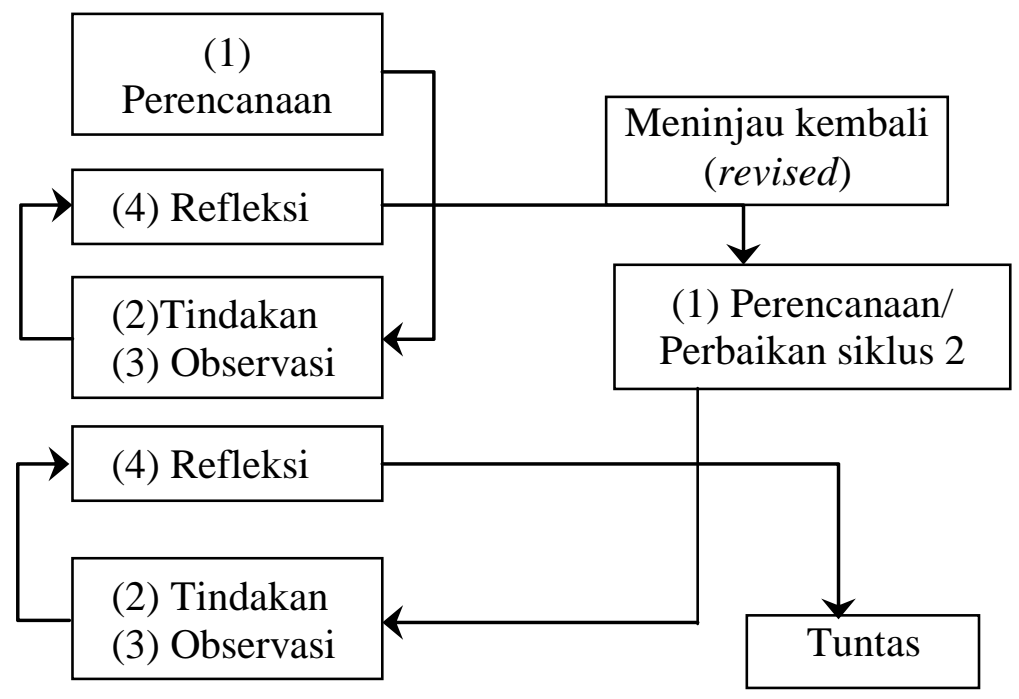

(Hopkins dalam Arikunto, 2006:126)

Maka peneliti menetapkan Strategi Pembelajaran A reaction to video karena pembelajaran ini mengatasi masalah kesulitan belajar. Penelitian ini dapat dilihat ketuntasan hasil belajar tabel berikut:

Ketuntasan Hasil Belajar Prasiklus

Siklus 1

\begin{tabular}{|l|c|c|}
\hline \multicolumn{1}{|c|}{ Nilai Siswa } & Jumlah Siswa & $\%$ \\
\hline Nilai $\geq 70$ & 16 & $50 \%$ \\
\hline Nilai $<70$ & 16 & $50 \%$ \\
\hline Jumlah & 32 & $100 \%$ \\
\hline
\end{tabular}

Kegiatan yang dilakukan pada tahap perencanaan ini adalah melaksanakan kegiatan sesuai dengan desain yang telah dibuat sebelumnya (seperti yang dijelaskan pada Bab III). Pada tahap ini semua persiapan yang telah dilakukan, setelah dilakukan diskusi antara guru, peneliti dan observer, baik yang berkaitan dengan persiapan mengajar (menyusun Silabus, RPP, Soal dan kunci jawaban) maupun persiapan lainnya meliputi membuat panduan observasi, mengajukan siswa yang akan menjadi anggota kelompok.

Pengamatan terhadap motivasi belajar siswadifokuskan pada beberapa hal, yaitu Minat dan perhatian siswa terhadap pelajaran, diskusi dan kesimpulan. Berdasarkan hasil observasi tersebut diketahui bahwa sebagian besar siswa telah 
mengikuti kegiatan pembelajaran dengan baik. Motivasi belajar siswadifokuskan pada beberapa hal, yaitu Minat dan perhatian siswa terhadap pelajaran, diskusi dan kesimpulan. Berdasarkan hasil observasi tersebut diketahui bahwa sebagian besar siswa mengikuti kegiatan pembelajaran dengan baik.

Hasil motivasi belajar siswa Siklus 1

\begin{tabular}{|l|c|c|c|c|c|c|c|}
\hline \multirow{2}{*}{ Motivasi belajar siswa } & \multicolumn{5}{|c|}{ Skor } & \multirow{2}{*}{$\%$} & Kategori \\
\cline { 2 - 9 } & 1 & 2 & 3 & 4 & & & Cukup Aktif \\
\hline $\begin{array}{l}\text { Minat dan perhatian siswa } \\
\text { terhadap pelajaran }\end{array}$ & 4 & 12 & 10 & 6 & 82 & 64 & Cukup Aktif \\
\hline Semangat belajar siswa & 8 & 7 & 0 & 17 & 90 & 70 & Cukup Aktif \\
\hline $\begin{array}{l}\text { Tanggung jawab siswa } \\
\text { terhadap tugas-tugas belajar }\end{array}$ & 0 & 25 & 0 & 7 & 78 & 61 & Cukup Aktif \\
\hline $\begin{array}{l}\text { Rasa senang siswa terhadap } \\
\text { tugas yang diberikan oleh } \\
\text { guru }\end{array}$ & 7 & 12 & 0 & 13 & 83 & 65 & \\
\hline $\begin{array}{l}\text { Reaksi siswa terhadap } \\
\text { stimulus yang diberikan oleh } \\
\text { guru }\end{array}$ & 0 & 8 & 15 & 9 & 82 & 64 & Cukup Aktif \\
\hline Motivasi Prasiklus & & \multicolumn{7}{|c|}{$65 \%$} & & \\
\hline
\end{tabular}

Sumber: Data primer diolah

Ketuntasan belajar siswa kelas VIII-A Siklus 1

\begin{tabular}{|l|c|c|}
\hline \multirow{2}{*}{\multicolumn{1}{|c|}{ Kondisi hasil belajar siswa }} & \multicolumn{2}{c|}{$\begin{array}{c}\text { Taraf Pencapaian } \\
\text { Sebelum Tindakan }\end{array}$} \\
\cline { 2 - 3 } & Jumlah & $\%$ \\
\hline Siswa yang mencapai ketuntasan belajar & 22 siswa & $69 \%$ \\
\hline Siswa yang belum mencapai ketuntasan belajar & 10 siswa & $31 \%$ \\
\hline Nilai rata-rata & 69,69 & \\
\hline
\end{tabular}

Sumber: Dokumen nilai ulangan harian 1 diolah

Dari tabel di atas diketahui bahwa ketuntasan hasil belajar dengan nilai capaian 70, maka 69\% siswa yang mencapai ketuntasan belajar. Sedangkan sebanyak $31 \%$ siswa belum memperoleh ketuntasan belajar. Rincian siswa yang belum tuntas belajar adalah sebanyak 10 orang atau $31 \%$ siswa dan sebanyak 22 orang atau $69 \%$ siswa yang tuntas. rata-rata hasil belajar siswa adalah 69,69. berdasarkan analisis hasil ulangan maka perlu diadakan siklus berikutnya.

Siklus 2

Pelaksanaan tindakan dilaksanakan 2 kali pertemuan, pertemuan pertama siklus II dilaksanakan pada hari Selasa tanggal 21 Maret 2017 selama 80 menit dari pukul 08.20-09.20 WIB dari pukul 08.20-09.20 WIB. Materi yang disajikan dalam kegiatan 
pembelajaran adalah Sistem tata surya. Uraian mengenai pelaksanaan tindakan dan hasil observasi pada masing-masing pertemuan pembelajaran dijabarkan berikut ini. Kegiatan diawal dengan guru memulai kegiatan belajar-mengajar dengan menjelaskan tujuan pembelajaran mampu memahami sistem tata surya dan mampu memahami sistem tata surya dengan komponen-komponen yang lain. Kegiatan inti dengan siswa memilih topik video yang diinginkan tentang sistem tata surya dan siswa mendownlod sendiri video namun website ditentukan oleh guru. Siswa menjelaskan apa yang harus dikritik bahwa ditiap-tiap kelompok ternyata bukan tentang sistem tata surya namun komponen tata surya. Guru meminta siswa untuk memutar video dengan Bluetooth ke teman yang lain dari kelompok 3 yang benar tentang sistem tata surya. Siswa mendiskusikan video yang diputar. Guru memberikan kesempatan kepada siswa untuk bisa mengembangkan ide-idenya sendiri dan mengungkapkan pendapat tentang hubungan antara pengalaman dengan pengetahuan yang mereka dapat saat itu. Hal itu dilakukan untuk melatih keberanian siswa dalam mengungkapkan pendapatnya, menambah pemahaman siswa dan merangsang pendapat siswa. Guru membahas dan menjelaskan secara garis besar materi pelajaran tersebut dikaitkan dengan pengalaman yang telah diungkapkan oleh siswa. Guru menunjukkan gambar dan berupa rublik di koran tentang tata surya.

Motivasi belajar siswapada masing-masing fokus observasi dapat dilihat pada tabel berikut ini.

Hasil Observasi motivasi belajar siswa Siklus 2

\begin{tabular}{|l|l|l|l|l|l|l|l|}
\hline \multirow{2}{*}{ Motivasi belajar siswa } & \multicolumn{5}{|c|}{ Skor } & \multirow{2}{*}{$\%$} & Kategori \\
\cline { 2 - 9 } & 1 & 2 & 3 & 4 & & & Sangat Aktif \\
\hline $\begin{array}{l}\text { Minat dan perhatian siswa } \\
\text { terhadap pelajaran }\end{array}$ & 0 & 5 & 10 & 17 & 108 & 84 & Sangat Aktif \\
\hline Semangat belajar siswa & 0 & 4 & 0 & 28 & 120 & 94 & Sangat Aktif \\
\hline $\begin{array}{l}\text { Tanggung jawab siswa } \\
\text { terhadap tugas-tugas belajar }\end{array}$ & 0 & 13 & 0 & 19 & 102 & 80 & \\
\hline $\begin{array}{l}\text { Rasa senang siswa terhadap } \\
\text { tugas yang diberikan oleh } \\
\text { guru }\end{array}$ & 1 & 1 & 0 & 30 & 123 & 96 & Sangat Aktif \\
\hline $\begin{array}{l}\text { Reaksi siswa terhadap } \\
\text { stimulus yang diberikan oleh } \\
\text { guru }\end{array}$ & 0 & 4 & 3 & 25 & 114 & 89 & Sangat Aktif \\
\hline Motivasi Prasiklus & & & & & & \\
\hline
\end{tabular}

Sumber: Data primer diolah

Tes hasil belajar dilakukan untuk mengetahui perubahan hasil belajar siswa setelah mengikuti Strategi Pembelajaran A reaction to video. Tes hasil belajar yang digunakan adalah tes uraian subjektif yang disusun sedemikian rupa menyesuaikan 
dengan karakteristik Strategi Pembelajaran A reaction to video. Hasil ulangan tersebut dapat dilihat pada Tabel 4.9 tersebut dibawah ini.

Ketuntasan Belajar Siswa Kelas VIII-A Siklus 2

\begin{tabular}{|l|c|c|}
\hline \multirow{2}{*}{\multicolumn{1}{|c|}{ Kondisi hasil belajar siswa }} & \multicolumn{2}{c|}{ Taraf Pencapaian Siklus 2 } \\
\cline { 2 - 3 } & Jumlah & $\%$ \\
\hline Siswa yang mencapai ketuntasan belajar & 29 siswa & $91 \%$ \\
\hline Siswa yang belum mencapai ketuntasan belajar & 3 siswa & $9 \%$ \\
\hline & 32 siswa & $100 \%$ \\
\hline
\end{tabular}

Sumber: Dokumen nilai ulangan harian 2 diolah

Kegiatan diskusi dengan guru dapat dilakukan dengan intensif. Kondisi ini telah menciptakan suasana komunikasi yang baik antara peneliti dan guru, sehingga maksud dari konsep penelitian dapat tersampaikan dengan baik. Selain itu suasana ini juga telah membentuk sebuah kolaborasi yang baik dengan guru. Berdasarkan dari kesepakatan hasil diskusi diputuskan untuk melakukan simulasi atau penerapan pembelajaran sebelum penelitian. Dari uraian di atas maka dapat disimpulkan pada siklus 1 mencapai persentase sebesar $67 \%=\frac{65 \%+70 \%}{2}$ meningkat $5 \%$ sehingga mencapai $91 \%$ $=\frac{89 \%+92 \%}{2}$ dengan kategori sangat aktif.

Dari uraian tentang indikator di atas maka penerapan pembelajaran yang dilakukan sebelum kegiatan penelitian membawa dampak yang baik. Bagi guru, guru merasa lebih siap dan memahami langkah demi langkah dalam penerapan Strategi Pembelajaran A reaction to video. Bagi siswa, siswa telah akrab terhadap pembelajaran yang dimaksud, sehingga siswa tidak akan canggung ketika harus terlihat aktif dalam proses pembelajaran ketika penelitian dilaksanakan. Bagi peneliti, dapat dijadikan sebuah pijakan untuk melakukan persiapan yang lebih matang ketika Strategi Pembelajaran A reaction to video diterapkan dalam penelitian.

Faktor kedua penentu keberhasilan adalah kondisi guru dan siswa. Kondisi guru ketiak melakukan tindakan dalam keadaan yang baik, sehingga guru dapat melaksanakan kegiatan pembelajaran dengan optimal. Selain itu guru sangat kooperatif, sehingga proses diskusi dan interaksi antara peneliti dan guru dapat dilakukan dengan baik sesuai dengan karakteristik PTK bahwa penelitian ini adalah penelitian kolaboratif yang melibatkan guru. 
Kondisi siswa ini dapat dilihat dari kesiapan siswa dalam mengikuti pembelajaran ini. Hal ini disebabkan oleh pembelajaran model ini telah dikenal sebelumnya oleh siswa, sehingga siswa mampu beradaptasi. Selain itu kebiasaan siswa yang sering berbicara sendiri ketika proses pembelajaran dapat diarahkan pada pembicaraan yang lebih bermanfaat.

\section{KESIMPULAN}

Berdasarkan pembahasan yang telah dilaksanakan pada bab sebelumnya, maka dapat ditarik kesimpulan bahwa:

1. penerapan strategi pembelajaran a reaction to video dapat meningkatkan motivasi belajar siswa mencapai 24\% dari 67\% siklus I menjadi 91\% siklus II IPA Fisika materi pokok sistem tata surya kelas VIII-A SMP Negeri 1 Situbondo Tahun Pelajaran 2016/2017.

2. penerapan strategi pembelajaran a reaction to video dapat meningkatkan hasil belajar siswa mencapai 19\% dari 69\% siklus I menjadi 91\% siklus II IPA Fisika materi pokok sistem tata surya kelas VIII-A SMP Negeri 1 Situbondo Tahun Pelajaran 2016/2017.

Dari uraian di atas maka sarannya sebagai berikut : Siswa dapat lebih memahami tentang manfaat dari diri tentang materi yang telah dipelajari kemudian dapat diaplikasikan materi tersebut dalam kehidupan sehari-hari serta dapat menerapkan setiap pembelajaran. Guru hendaknya bisa berinovasi dalam melaksanakan pembelajaran lebih dengan adanya Strategi Pembelajaran A reaction to video ini. Kepala sekolah hendaknya memotivasi setiap guru untuk berinovasi dalam penerapan Strategi Pembelajaran A reaction to video sehingga hasil belajar yang diharapkan bisa tercapai. 


\section{DAFTAR PUSTAKA}

Arikunto, 2006. Prosedur Penelitian Suatu Pendekatan Praktik, Ed Revisi VI, Jakarta: PT Rineka Cipta.

Darmayah, 2010. Strategi Pembelajaran Menyenangkan Dengan Humor. Jakarta: Bumi Aksara.

Daryanto, 2009. Panduan Proses Pembelajaran Kreatif \& Inovatif. Jakarta: Publisher Depdiknas, 2003. Kurikulum 2004 Standart Kompetensi. Jakarta: Puskur. Dit. PTKSD Dimyati dan Mudjiono, 2009. Belajar dan Pembelajaran. Jakarta: PT. Rineka Cipta. Etin Solihatin, 2012. Strategi Pembelajaran. Jakarta: Bumi Aksara

Handoko. 2013. Manajemen Personalia dan Sumber Daya Manusia. Yogyakarta: BPFE Hamalik, 2014. Kurikulum dan Pembelajaran. Jakarta: Bumi Aksara

Hariyanto, 2009. Belajar dan Pembelajaran. Bandung: PT Remaja Rosdakarya

Hobri, 2006. Model-Model Pembelajaran Inovatif. Fakultas Keguruan dan Ilmu Pendidikan Universitas Jember.

Hobri, 2007. Penelitian Tindakan Kelas (PTK). Jember: UPTD Balai Pengembangan Pendidikan (BPP)

Kusniasih, 2015. Model Pembelajaran. Yogyakarta: Kata Pena

Muhibbin Syah, 2000. Psikologi Pendidikan dan Pendekatan Baru. Bandung: PT Remaja Rosdakarya

Muhibbin Syah, 2010. Psikologi Pendidikan dengan Pendekatan Baru. Bandung: PT Remaja Rosdakarya

Ngalimun, 2012. Strategi dan Model Pembelajaran. Yogyakarta: Aswaja Pressindo

Ningtiash, 2007. Dasar-Dasar Kependidikan. Jakarta: Ditjen Bimbaga Islam.

Slameto, 2005. Belajar dan Faktor-faktor yang Mempengaruhinya. Jakarta: Rineka Cipta

Sudirman. 2006. Proses Belajar Mengajar Di Sekolah. Jakarta : Rineka Cipta.

Sudjana, 2002. Penilaian Hasil Proses Belajar Mengajar. Bandung: PT Remaja Rosdakarya

Sudjana, 2006. Penilaian Hasil Proses Belajar Mengajar. Bandung: PT Remaja Rosdakarya

Sudjana, 2009. Penilaian Hasil Proses Belajar Mengajar. Bandung: PT Remaja Rosdakarya.

Sukarni, 2001. Petunjuk Praktis Penelitian Tindakan Kelas. S e m a r a n g: U N N E S

Surya Subrata, 2003. Psikologi Pendidikan. Jakarta: PT. Grafindo Perkasa Rajawali.

Usman, 2007. Menjadi Guru Profesional. Bandung : Remaja Rosdakarya

Warsono dan Hariyanto, 2012. Pembelajaran Aktif (Teori dan Asesmen). Bandung: Remaja Rosdakarya

Zuriah, 2003. Penilaian Pencapaian Hasil Belajar, Yogyakarta: Universitas Negeri Yogyakarta. 